\title{
Inhibition of ERK1/2 Signaling Pathway is Involved in Melatonin's Antiproliferative Effect on Human MG-63 Osteosarcoma Cells
}

\author{
Lifeng Liu ${ }^{\mathrm{a}}$ Ying $\mathrm{Xu}^{\mathrm{b}}$ Russel J. Reiter ${ }^{\mathrm{c}}$ Yutao Pan ${ }^{\mathrm{a}}$ Di Chen ${ }^{\mathrm{a}}$ Yangzhou Liu ${ }^{\mathrm{a}}$ \\ Xingyu $\mathrm{Pu}^{\mathrm{a}}$ Liguo Jiang ${ }^{\mathrm{a}}$ Zengchun $\mathrm{Li}^{\mathrm{a}}$
}

\begin{abstract}
aDepartment of Trauma Orthopaedics, Shanghai East Hospital, Tongji University School of Medicine, ${ }^{b}$ State Key Laboratory of Molecular Biology, Institute of Biochemistry and Cell Biology, Shanghai Institutes for Biological Sciences, Chinese Academy of Sciences, Shanghai, China, 'Department of Cellular \& Structural Biology, UT Health Science Center, San Antonio, Texas, USA
\end{abstract}

\section{Key Words}

Melatonin • Osteosarcoma • ERK1/2 • Cell cycle

\begin{abstract}
Background: In a previous study, we found that melatonin inhibits MG-63 osteosarcoma cell proliferation; however, the underlying mechanisms remain elusive. Mitogen-activated protein kinase (MAPK) and Akt signaling pathways play key roles in the anticancer effects of melatonin. Aims: The present study investigated whether MAPK and Akt signaling pathways are involved in melatonin's antiproliferative actions on the human MG-63 osteosarcoma cells. Methods/Results: Western blot analysis confirmed that melatonin significantly inhibited phosphorylation of ERK1/2 but not p38, JNK, or Akt. The expression of ERK1/2, p38, JNK, and Akt was not altered by melatonin. PD98059 and melatonin alone, and especially in combination, significantly inhibited cell proliferation. The changes included $\mathrm{G}_{1}$ and $\mathrm{G}_{2} / \mathrm{M}$ phase arrest of the cell cycle, and a downregulation of the expression at both the protein and mRNA levels of cyclin D1 and CDK4 (related to the $\mathrm{G}_{1}$ phase) and of cyclin B1 and CDK1 (related to the $\mathrm{G}_{2} / \mathrm{M}$ phase) as measured by flow cytometry after propidium iodide staining, and both western blot and real-time PCR, respectively. Furthermore, the combination of PD98059 and melatonin synergistically and markedly augmented the action of either agent alone. Co-immunoprecipitation further confirmed that there was an interaction between p-ERK1/2 and cyclin D1, CDK4, cyclin B1, or CDK1, which was blunted in the presence of melatonin or PD98059. Conclusion: These findings suggest that melatonin's antiproliferative action is mediated by inhibition of the ERK1/2 signaling pathway rather than the $\mathrm{p} 38$, JNK, or Akt pathways.




\section{Introduction}

Since the introduction of chemotherapy, survival in osteosarcoma patients has improved considerably. Still, there is no worldwide consensus on the efficacy of treatment or a reduction in the severity or fewer side effects of the chemotherapy approach [1]. Importantly, a recent meta-analysis indicated that melatonin as an adjuvant therapy for cancer may lead to substantial improvements in tumor remission, 1-year survival, and alleviation of radiochemotherapy-related side effects [2]. Our previous study documents that melatonin inhibits cell proliferation of the human MG-63 osteosarcoma cell line [3]. This suppressive action involves the downregulation of cyclin D1 and CDK4 (related to the $\mathrm{G}_{1}$ phase) and of cyclin B1 and CDK1 (related to the G2/M phase). The current study is designed to help further clarify the mechanisms by which melatonin inhibits the activity of MG-63 osteosarcoma cells.

Mitogen-activated protein kinase (MAPK) and Akt signaling pathways are responsible for melatonin's antiproliferative actions in some cells, including human umbilical vein endothelial cells [4], human fibroblast-like synoviocyte [5], hepatocarcinoma HepG2 cells [6], human melanoma SK-MEL-1 cells [7], rat glioma cells [8, 9], human breast adenocarcinoma MCF-7 cells $[10,11]$, and human osteoblasts [12]. The MAPK family mainly consists of extracellular signal-regulated kinase (ERK1/2), p38, and c-Jun N-terminal kinase (JNK). The ERK1/2 cascade, activated by mitogenic stimuli, is critical for cell proliferation and survival $[13,14]$ and is required for normal progression into mitosis $[15,16]$. The p38 and JNK pathways are activated in response to chemicals and environmental stress [17-19]. Akt (also known as Akt1), a mediator of growth factor-induced cell survival [20-22], may promote cell proliferation via phosphorylation [23].

Herein, we demonstrate that the inhibition of ERK1/2 signaling pathway involves melatonin-induced $\mathrm{G}_{1}$ and $\mathrm{G}_{2} / \mathrm{M}$ phase arrest in the human MG-63 osteosarcoma cell line by downregulating the expression of cyclin D1, CDK4, cyclin B1 and CDK1; this inhibitory action is potentially mediated via the ERK1/2 but not the p38, JNK, or Akt pathways. Information garnered from this study provides insight into the mechanisms of melatonin-mediated cell cycle arrest and has implications for exploring treatment of osteosarcoma with melatonin.

\section{Materials and Methods}

\section{Cell culture and reagents}

The human osteosarcoma cells (MG-63 cells) were maintained in a Dulbecco's Modified Eagle's Medium (Gibco, Life Technologies, Carlsbad, USA), supplemented with $10 \%$ fetal bovine serum (FBS) (HyClone, Thermo, Fremont, USA), in a humidified $5 \% \mathrm{CO}_{2}$ atmosphere at $37^{\circ} \mathrm{C}$; the medium was changed every other day. The MG-63 cells were plated at $10^{4}$ cells $/ \mathrm{cm}^{2}$ for $24 \mathrm{~h}$ before treatment. Melatonin solution was prepared as follows: a melatonin stock solution in 100\% dimethyl sulfoxide (DMSO) was serially diluted with culture media in accordance with the tested doses; the culture media contained $0.2 \%$ DMSO and $10 \%$ serum in every concentration of melatonin or vehicle group.

Melatonin, PD98059, the 3-(4,5-dimethyl-thiazol-2-yl)-2,5-diphenyl-tetrazoliumbromide (MTT), and propidium iodide (PI) were obtained from Sigma (St. Louis, MO, USA). Primary monoclonal antibodies for ERK1/2, phospho-ERK1/2, p38, phospho-p38, JNK, phospho-JNK, Akt, phospho-Akt, IgG, and $\beta$-actin were purchased from Cell Signaling Technology (Danvers, MA, USA) and cyclin B1, cyclin D1, CDK1, and CDK4 were from Lab Vision (Thermo, Fremont, CA, USA).

Western blotting

After treatment with $4 \mathrm{mM}$ melatonin for $4 \mathrm{~h}, 24 \mathrm{~h}$, or $48 \mathrm{~h}$ or $50 \mu \mathrm{M}$ PD98059 for $24 \mathrm{~h}$, the cells were extracted with lysis buffer (150 mM NaCl, $1 \% \mathrm{NP}-40,0.1 \% \mathrm{SDS}, 2 \mu \mathrm{g} / \mathrm{mL}$ aprotinin, $1 \mathrm{mM}$ PMSF) for $30 \mathrm{~min}$ at $4{ }^{\circ} \mathrm{C}$. Extracts were centrifuged at $12,000 \mathrm{~g}$ for $15 \mathrm{~min}$ at $4{ }^{\circ} \mathrm{C}$. Supernatants containing total protein were harvested. Aliquots, each containing $50 \mu \mathrm{g}$ of protein, were separated by a $10 \%$ SDS-PAGE and 


\section{Cellular Physiology Cell Physiol Biochem 2016;39:2297-2307 \begin{tabular}{l|l|l} 
and Biochemistry & Dublished online: November 07, 2016 & $\begin{array}{l}\text { (c) } 2016 \text { The Author(s). Published by S. Karger AG, Basel } \\
\text { www.karger.com/cpb }\end{array}$
\end{tabular}}

Liu et al.: ERK1/2 Involves Melatonin-inhibited Osteosarcoma Cell Proliferation

transferred to PVDF membranes at $60 \mathrm{~V}$ (Akt, phospho-Akt, and cyclin B1) or $40 \mathrm{~V}$ (the others) for $2 \mathrm{~h}$ at low temperature. The membranes were blocked in $5 \%$ bovine serum albumin (phospho-) or skimmed milk (the others) for $2 \mathrm{~h}$. Subsequently, proteins were detected using monoclonal antibodies at 1:200 (cyclin B1, cyclin D1, CDK1, and CDK4), 1:500 (phospho-JNK), 1:1900 (phospho-ERK1/2), or 1:1000 (the others) dilution overnight at $4{ }^{\circ} \mathrm{C}$; they were then visualized using anti-mouse or anti-rabbit IgG conjugated with horse radish peroxidase (HRP) at 1:6000 (cyclin B1, cyclin D1, CDK1, and CDK4) or 1:8000 (the others) dilution for $2 \mathrm{~h}$ at room temperature, respectively. An EC3 Imaging System (UVP LLC, Upland, CA, USA) was used to identify the specific bands, and the optical density of each band was measured using Gel-Pro Analyzer 4.0 software (Media Cybernetics, Inc., Bethesda, MD, USA). The difference between the proteins of interest and $\beta$-actin of the same sample was calculated as relative content and presented graphically.

\section{Cell proliferation assay}

Cell proliferative activities were determined using MTT method. Briefly, MG-63 cells were seeded onto 96-well plates (4,000 cells/well) for $24 \mathrm{~h}$ and the medium was then replaced with $10 \%$ serum medium containing 0.2\% DMSO, $50 \mu \mathrm{M}$ PD98059, 4 mM melatonin, or both $50 \mu \mathrm{M}$ PD98059 and $4 \mathrm{mM}$ melatonin for $24 \mathrm{~h}, 48 \mathrm{~h}$ or $72 \mathrm{~h}$. After treatment, culture media were changed for serum-free culture media. MTT dissolved in phosphate buffer saline (PBS) was added to each well and incubated for $4 \mathrm{~h}$ at $37^{\circ} \mathrm{C}$. Then, the serum-free culture media containing MTT were discarded and DMSO was added to each to dissolve the precipitate. The optical densities were measured at $490 \mathrm{~nm}$ spectral wavelength using a microplate reader (Spectra Thermo, Männedorf, Switzerland). Viability results were expressed as percentages.

\section{Cell cycle analysis}

After treatment with 0.2\% DMSO, $50 \mu \mathrm{M}$ PD98059, $4 \mathrm{mM}$ melatonin, or both $50 \mu \mathrm{M}$ PD98059 and $4 \mathrm{mM}$ melatonin for $24 \mathrm{~h}$, cells were harvested and washed twice with ice-cold PBS, and fixed in $75 \%$ ethanol for overnight at $4{ }^{\circ} \mathrm{C}$. The fixed cells were again rinsed with PBS and resuspended in $0.5 \mathrm{~mL}$ PI staining solution containing $50 \mu \mathrm{g} / \mathrm{mL} \mathrm{PI,} 0.25 \%$ Triton X-100, and $0.2 \mathrm{mg} / \mathrm{mL}$ DNase-free RNase for $30 \mathrm{~min}$ at room temperature in the dark. 10,000 events per sample were acquired with a FACS SCAN flow cytometer (Becton-Dickinson, San Jose, CA, USA) and the percentage of cells in $\mathrm{G}_{0} / \mathrm{G}_{1}$, $\mathrm{S}$ and $\mathrm{G}_{2} / \mathrm{M}$ phases of the cell cycle was determined using Modfit LT 3.0 (Becton-Dickinson).

\section{Real-time PCR}

Total RNA was isolated from cells using TRIzol reagent (Invitrogen, Life Technologies, Carlsbad, CA, USA) according to the manufacturer's instructions. Total RNA was reverse transcribed using a reversetranscription kit (TaKaRa, Dalian, China) according to the manufacturer's protocols. Real-time PCR was performed on ABI Prism 7900HT Fast System (Applied Biosystems, Life technologies, Foster, CA, USA) using SYBR Premix Ex Taq ${ }^{\text {TM }}$ II (TaKaRa). Amplifications were carried out in a total volume of $20 \mu \mathrm{L}$ and cycled 40 times after the initial denaturation $\left(95^{\circ} \mathrm{C}\right.$ for $30 \mathrm{~s}$ ) with the following parameters: $95^{\circ} \mathrm{C}$ for $5 \mathrm{~s}$ and $60{ }^{\circ} \mathrm{C}$ for $30 \mathrm{~s}$. Primer sequences were reported previously [23] and $\beta$-actin was used as an internal control. The reliability of results was supported by analyzing the dissociation curve. Real-time PCR data were calculated using $2^{-\Delta \Delta \mathrm{CT}}$ Method by the SDS 2.4 software package (Applied Biosystems).

\section{Co-immunoprecipitation}

After treatment with melatonin or PD98059 for $24 \mathrm{~h}$, cells were extracted with lysis buffer (10 mM $\mathrm{KCl}, 1.5 \mathrm{mM} \mathrm{MgCl} 2,10 \mathrm{mM}$ HEPES, $1 \mathrm{mM}$ PMSF, $1 \mathrm{mM}$ DTT) and homogenized for $30 \mathrm{~min}$ at $4{ }^{\circ} \mathrm{C}$. The extracts were centrifuged at $12,000 \mathrm{~g}$ for $15 \mathrm{~min}$ at $4{ }^{\circ} \mathrm{C}$, and then the supernatants containing total protein were harvested. Equal amounts of protein were, respectively, exposed to equal amounts of monoclonal antibodies against p-ERK1/2, IgG, cyclin D1, CDK4, cyclin B1, or CDK1, which were immobilized on protein $\mathrm{A} / \mathrm{G}$ beads (Beyotime, Haimen, China). Following 3-h incubation at $4{ }^{\circ} \mathrm{C}$ with gentle rotation, beads were washed extensively five times with lysis buffer, boiled, and microcentrifuged. Proteins were detected with monoclonal antibodies against p-ERK1/2, cyclin D1, CDK4, cyclin B1, or CDK1 by western blot. To ensure the data validity and repeatability, the MG-63 cells used in the experiments were from the same treated batch.

\section{KARGER}




\section{Cellular Physiology Cell Physiol Biochem 2016;39:2297-2307 \begin{tabular}{l|l|l} 
and Biochemistry $\begin{array}{l}\text { DOI: 10.1159/000447922 } \\
\text { Published online: November 07, 2016 }\end{array}$ & $\begin{array}{l}\text { (c) } 2016 \text { The Author(s). Published by S. Karger AG, Basel } \\
\text { www.karger.com/cpb }\end{array}$
\end{tabular}}

Liu et al.: ERK1/2 Involves Melatonin-inhibited Osteosarcoma Cell Proliferation

Statistical analysis

Data were analyzed using SPSS 16.0 software. An independent-samples t test or a one-factor analysis of variance was used to evaluate the differences between groups with various treatments, and least significant difference (LSD) test was used for post hoc subgroup analysis. All data were presented as mean \pm S.E.M. of at least three independent experiments. Results were considered statistically significant when the p-value was less than 0.05 . $\mathrm{N}$-fold values in gene expression below 0.5 and up to 2 were taken as significant in accordance with values obtained from control genes [24].

\section{Results}

Melatonin significantly inhibited phosphorylation of ERK1/2 but not p38, JNK, or Akt

Previously, we confirmed that $4 \mathrm{mM}$ melatonin has an antiproliferative effect by inducing $\mathrm{G}_{1}$ and $\mathrm{G}_{2} / \mathrm{M}$ phase arrest in human MG-63 osteosarcoma cells [3]. MAPK and Akt signaling pathways play a critical role in melatonin-induced antiproliferative events in other cells [4-12]. To determine whether MAPK and Akt signaling pathways are involved in the antiproliferative action of melatonin in MG-63 cells, the expression of MAPK components and Akt was evaluated using the western blot method. We found that melatonin significantly inhibited phosphorylation of ERK1/2 (p-ERK1/2) but not p38 (p-p38), JNK (p-JNK), or Akt (p-Akt) in a time-dependent manner, compared with control cells at various time points examined. The expression of ERK1/2, p38, JNK, and Akt was not altered (Fig. 1).

\section{Inhibition of ERK1/2 signaling pathway is involved in melatonin-induced antiproliferative} effect

To further test whether the inhibition of ERK1/2 signaling pathway is involved in melatonin-induced the antiproliferative action in this osteosarcoma cell line, the cells were treated with PD98059, a selective inhibitor of MEK that disrupts downstream activation of ERK1/2. Because of previously published data $[25,26]$ and the results of our preliminary experiment, PD98059 at $50 \mu \mathrm{M}$ concentrations was used (inhibiting only the ERK pathway, data not shown). As shown in Fig. 2, treatment with PD98059 (50 $\mu \mathrm{M})$ or melatonin for 24 $\mathrm{h}$ alone, and especially in combination, effectively blocked the ERK1/2 activation in MG-63 cells, compared with control cells. Also, the proliferation assay using MTT method showed

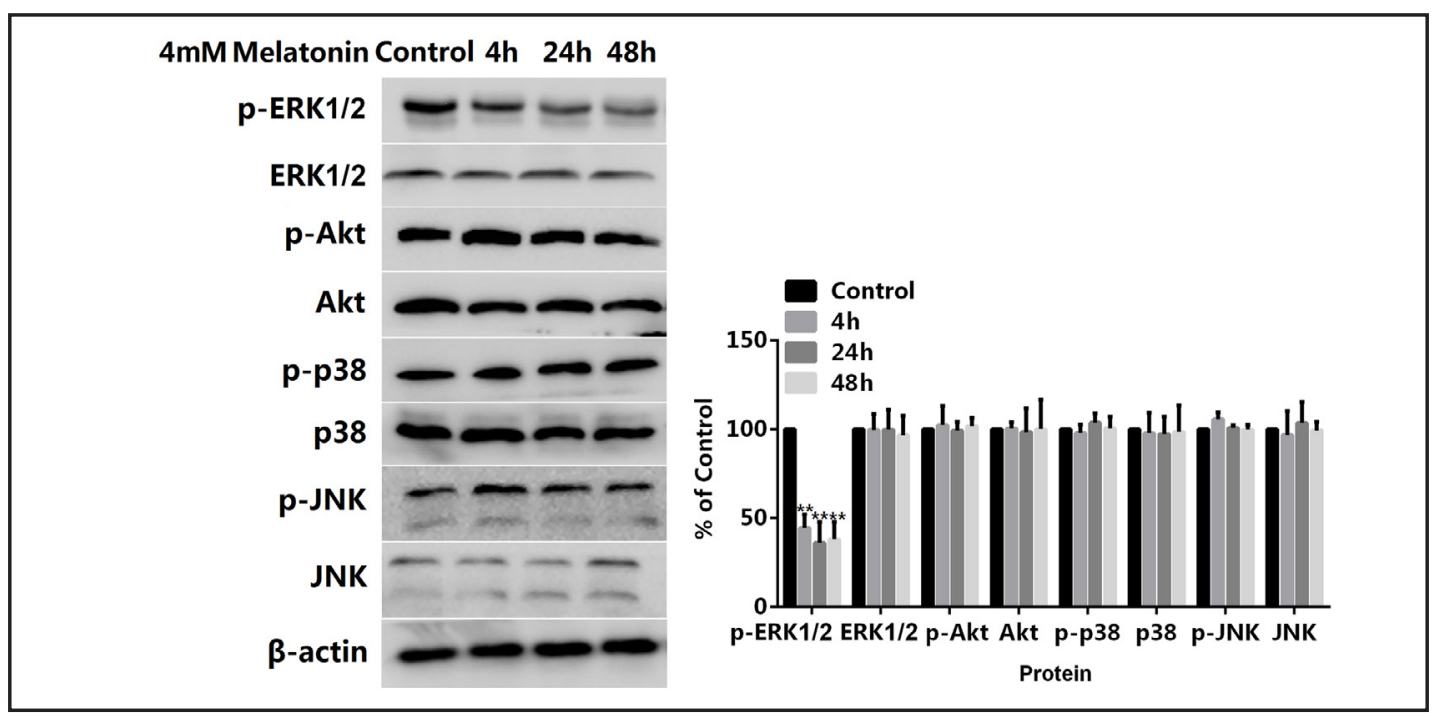

Fig. 1. Effect of melatonin on the expression of ERK1/2, p38, JNK, and Akt in MG-63 cells. The cells were treated with vehicle or $4 \mathrm{mM}$ melatonin for $4 \mathrm{~h}, 24 \mathrm{~h}$, or $48 \mathrm{~h}$. After treatment, total and phosphorylated (p-) expression levels were evaluated using western blot. Each bar represents the mean \pm S.E.M. of three independent experiments. ${ }^{* *} \mathrm{P}<0.01$, compared with control cells. 


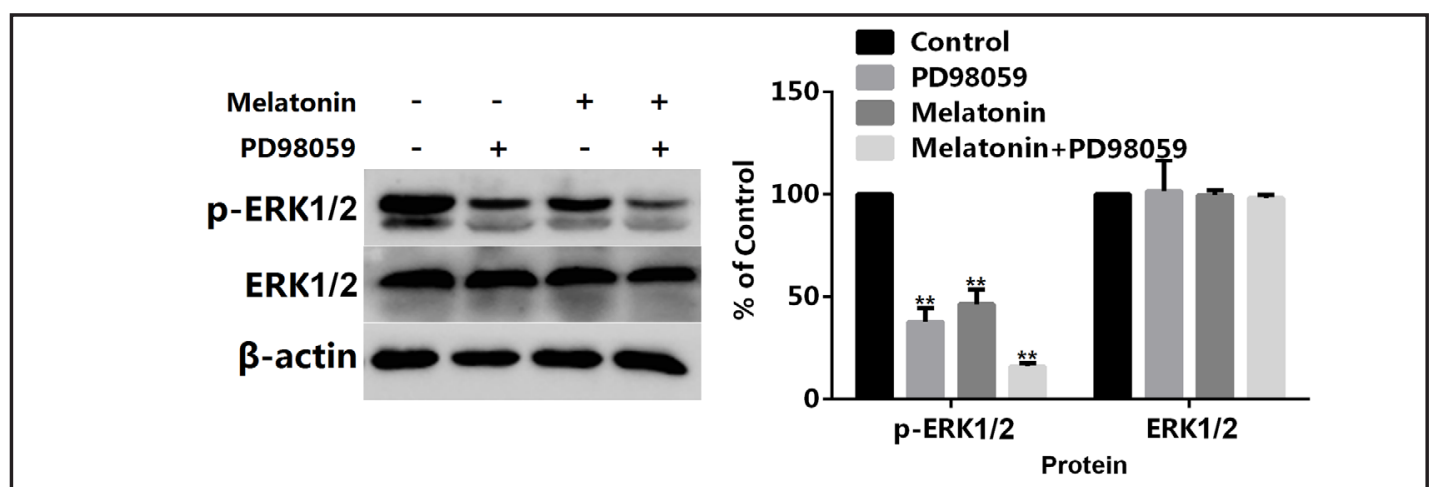

Fig. 2. Effects of melatonin or PD98059 alone, or in combination, on the expression of ERK1/2 in MG-63 cells. The cells were treated with vehicle or melatonin (4 mM) and PD98059 (50 $\mu \mathrm{M})$ alone, or in combination, for $24 \mathrm{~h}$. After treatment, total and phosphorylated (p-) expression levels were estimated using western blot. Each bar represents the mean \pm S.E.M. of three independent experiments. ${ }^{* *} \mathrm{P}<0.01$, compared with control cells.

Fig. 3. Effects of melatonin or PD98059 alone, or in combination, on proliferation of MG-63 cells. The cells were treated with vehicle or melatonin $(4 \mathrm{mM})$ and PD98059 $(50 \mu \mathrm{M})$ alone, or in combination, for 24 h, $48 \mathrm{~h}$ or $72 \mathrm{~h}$. Cell vitality was estimated using the MTT assay. Results are presented as relative percentage of untreated cells at $0 \mathrm{~h}$. Each bar represents the mean \pm S.E.M. of three independent experiments. ${ }_{\# \#}^{* *} \mathrm{P}$ $<0.01$, compared with control cells. $\mathrm{P}<0.05$ or $\mathrm{P}$ $<0.01$, compared with cells co-treated with melatonin and PD98059.

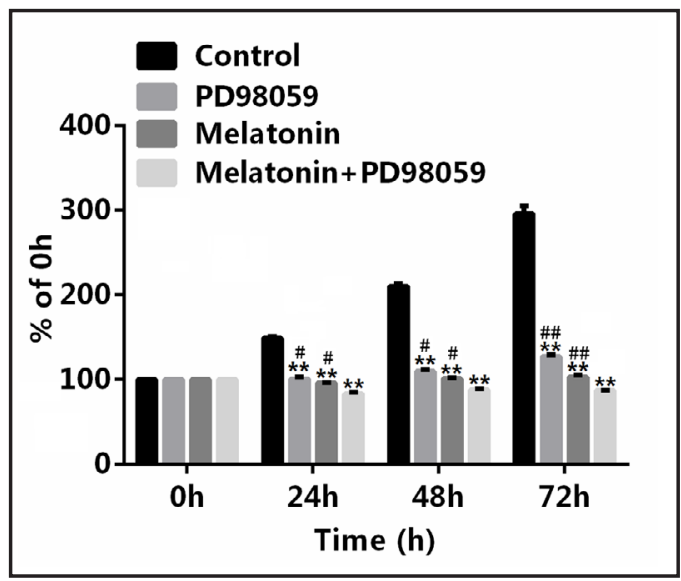

that PD98059 or melatonin alone, and especially in combination, significantly inhibited osteosarcoma cell proliferation at various time points examined, compared with control cells (Fig. 3). The results are consistent with the fact that the inhibition of ERK1/2 signaling pathway is associated with melatonin-induced antiproliferative effect on osteosarcoma cells.

Melatonin-induced $G_{1}$ and $G_{2} / M$ phase arrest is related to the inhibition of ERK1/2 signaling pathway

To determine whether the inhibition of ERK1/2 signaling pathway alters cell cycle distribution, flow cytometry was performed after PI staining. We found that PD98059 and melatonin alone, and especially in combination, significantly increased the fraction of cells in $\mathrm{G}_{0} / \mathrm{G}_{1}$ phase of the cell cycle while simultaneously reducing the proportion in the G2/M phase rather than the S phase, compared with control cells (Fig. 4). The combination synergistically and markedly reinforced the alterations in the cell cycle distribution (CompuSyn software analysis: CI values $<1$ ). This suggests that melatonin-induced $\mathrm{G}_{1}$ and $\mathrm{G}_{2} / \mathrm{M}$ phase arrest is related to the inhibition of ERK1/2 signaling pathway.

Inhibition of ERK1/2 signaling pathway is implicated in melatonin-induced downregulation of expression levels of cyclin D1, CDK4, cyclin B1 and CDK1

To examine whether the inhibition of ERK1/2 signaling pathway contributes to downregulation of the expression levels of cyclin D1 and CDK4 (related to the G1 phase) and of cyclin B1 and CDK1 (related to the G2/M phase), western blot and real-time 


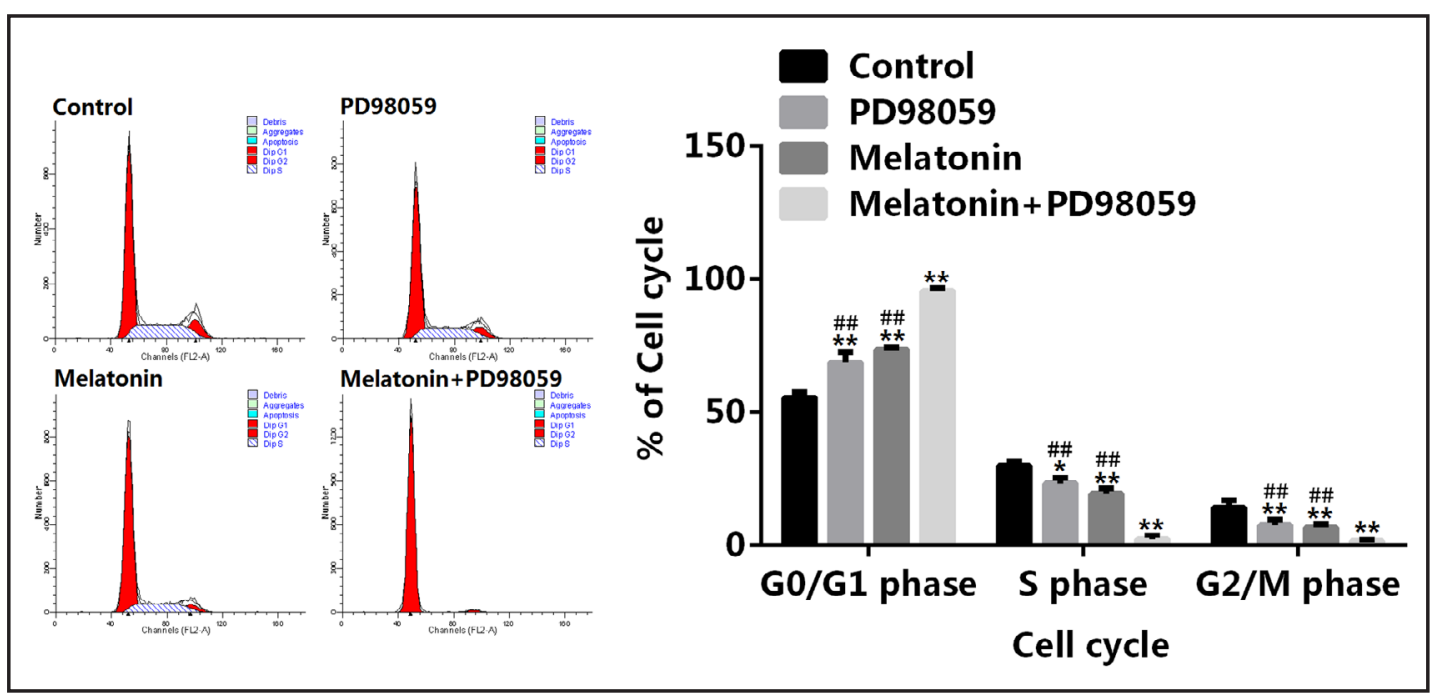

Fig. 4. Effects of melatonin or PD 98059 alone, or in combination, on cell cycle distribution of MG-63 cells. The cells were treated with vehicle or melatonin ( $4 \mathrm{mM})$ and PD98059 (50 $\mu \mathrm{M})$ alone, or in combination, for $24 \mathrm{~h}$, and cell cycle distribution was estimated using flow cytometry as described in Methods. Represen-

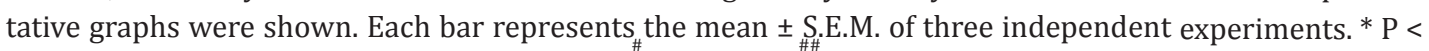
0.05 or ${ }^{* *} \mathrm{P}<0.01$, compared with control cells. $\mathrm{P}<0.05$ or $\quad \mathrm{P}<0.01$, compared with cells co-treated with melatonin and PD98059.

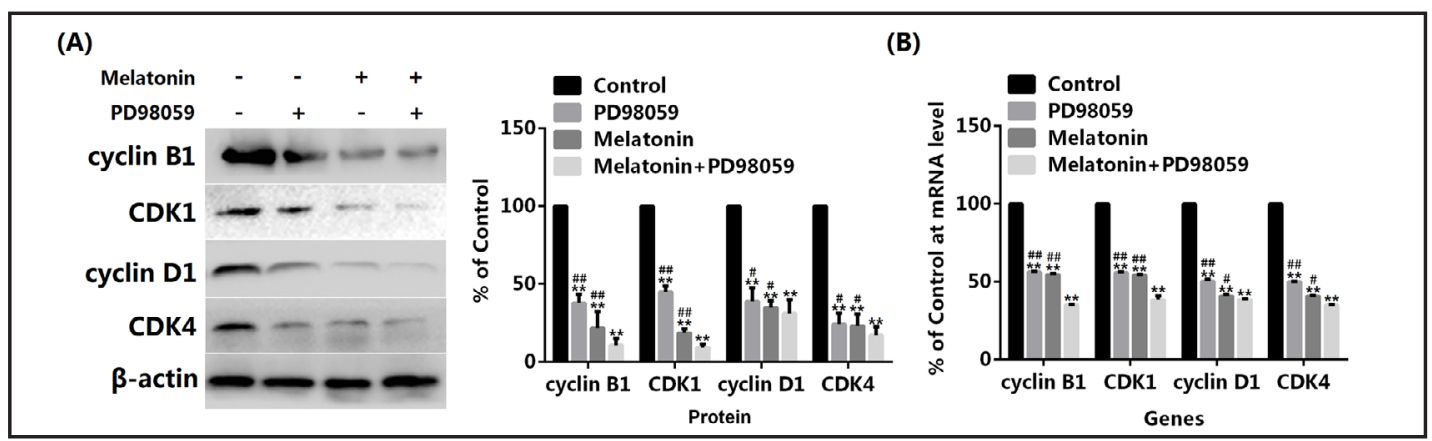

Fig. 5. Effect of melatonin or PD98059 alone, or in combination, on the expression of cyclins and cyclin-dependent kinases in MG-63 cells. The cells were treated with vehicle or melatonin (4 mM) and PD98059 (50 $\mu \mathrm{M}$ ) alone, or in combination, for $24 \mathrm{~h}$, and the expression of cyclin D1, CDK4, cyclin B1 and CDK1 at both protein (A) and mRNA (B) levels was estimated using western blot (A) and real-time PCR (B) analyses as described in Methods. Each bar represents the mean \pm S.E.M. of three independent experiments. ${ }^{* *} \mathrm{P}<$ 0.01 , compared with control cells. $\mathrm{P}<0.05$ or $\mathrm{P}<0.01$, compared with cells co-treated with melatonin and PD98059.

PCR assays were performed. We found that PD98059 and melatonin alone, and especially in combination, significantly reduced their expression at both protein and mRNA levels, compared with control cells (Fig. 5). This shows that the inhibition of ERK1/2 signaling pathway is implicated in melatonin-induced downregulation of expression levels of cyclin D1, CDK4, cyclin B1 and CDK1.

There is an interaction between $p$-ERK1/2 and cyclin D1, CDK4, cyclin B1, or CDK1

Finally, to identify whether there is an interaction between p-ERK1/2 and cyclin D1, CDK4, cyclin B1, or CDK1, co-immunoprecipitation was performed. The MG-63 cells in the absence or presence of melatonin for $24 \mathrm{~h}$ were subjected to immunoprecipitation with antibodies against p-ERK1/2 or IgG, followed by western blotting for cyclin D1, CDK4, cyclin 


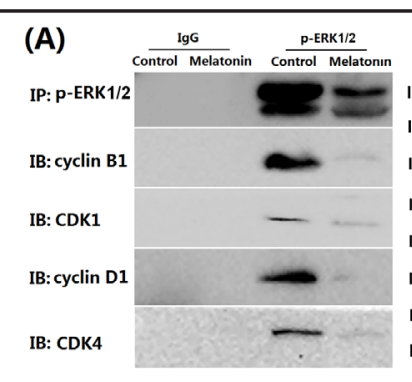

(A)

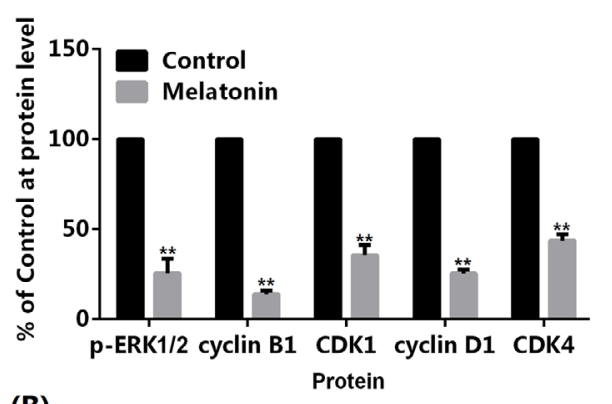

(B)
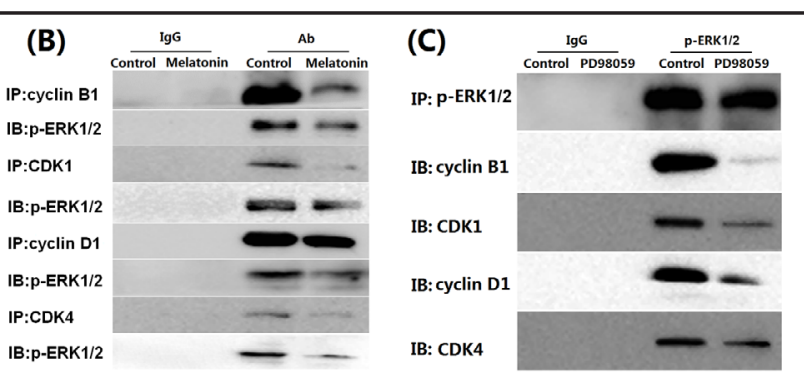

(C)

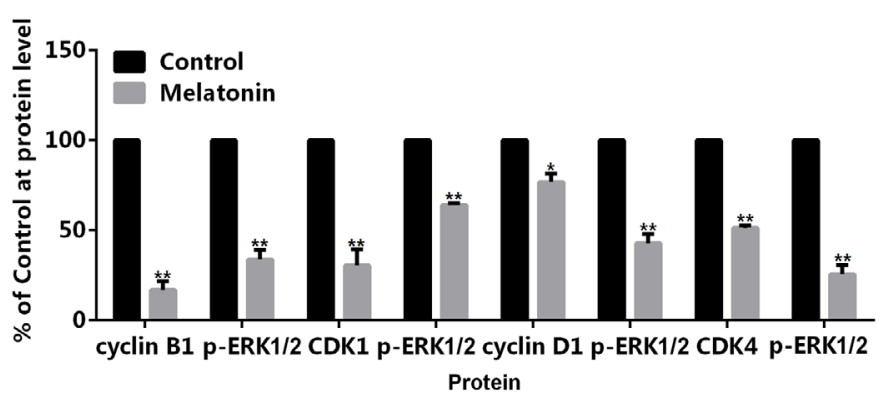

Fig. 6. The interaction between p-ERK1/2 and cyclin D1, CDK4, cyclin B1, or CDK1 in the absence or presence of melatonin or PD98059 in MG-63 cells. The cells in the absence or presence of melatonin (4 mM) for $24 \mathrm{~h}$ were subjected to immunoprecipitation with antibodies against p-ERK1/2 or IgG, followed by western blotting for cyclin D1, CDK4, cyclin B1, and CDK1 (A). Reciprocal immunoprecipitation with antibodies against cyclin D1, CDK4, cyclin B1, CDK1, or IgG were analyzed by western blotting for p-ERK1/2 (B). The cells in the absence or presence of PD98059 $(50 \mu \mathrm{M})$ for $24 \mathrm{~h}$ were subjected to immunoprecipitation with p-ERK1/2 or IgG antibodies followed by western blotting for cyclin D1, CDK4, cyclin B1, and CDK1 (C). The graph labeled "A", "B" or "C" respectively corresponds to the blot displayed as "A", "B" or "C". The results were normalized in accordance with the data of treated groups as a percentage of each corresponding control group. Each bar represents the mean \pm S.E.M. of three independent experiments. ${ }^{*} \mathrm{P}<0.05$ or ${ }^{* *} \mathrm{P}<0.01$, compared with control cells.

B1, or CDK1. An evident interaction between p-ERK1/2 and cyclin D1, CDK4, cyclin B1, or CDK1 was observed. In contrast, this interaction was weakened when the cells were treated with melatonin for $24 \mathrm{~h}$ (Fig. 6A). Reciprocal immunoprecipitation with antibodies against cyclin D1, CDK4, cyclin B1, CDK1, or IgG was assessed by western blotting for p-ERK1/2, and again, the interaction between p-ERK1/2 and cyclin D1, CDK4, cyclin B1, CDK1 was salient, which was attenuated in the presence of melatonin (Fig. 6B). Cells in the absence or presence of PD98059 for $24 \mathrm{~h}$ were subjected to immunoprecipitation with antibodies against p-ERK1/2 or IgG, followed by western blotting for cyclin D1, CDK4, cyclin B1, and CDK1. The interaction between p-ERK1/2 and cyclin D1, CDK4, cyclin B1, or CDK1 was weakened in response to PD98059 exposure (Fig. 6C). 


\section{Cellular Physiology Cell Physiol Biochem 2016;39:2297-2307 \\ and Biochemistry Published online: November 07, 2016 \begin{tabular}{l|l} 
DOI: 10.1159/000447922 2016 The Author(s). Published by S. Karger AG, Basel \\
www.karger.com/cpb
\end{tabular}}

Liu et al.: ERK1/2 Involves Melatonin-inhibited Osteosarcoma Cell Proliferation

\section{Discussion}

Melatonin plays key roles in the biologic regulation of circadian rhythms [27, 28], sleep $[29,30]$, antioxidant protection [31-35], cell aging [36], tumor growth [12, 37], reproduction $[31,38]$, and bone physiology $[39,40]$. A growing amount of data indicates that the age-related decline in the level of melatonin is closely associated with bone diseases: osteosarcoma, adolescent idiopathic scoliosis and osteoporosis [1,39]. Available information regarding the influence of melatonin, especially at mM concentrations, on abnormal osteoblast, such as osteosarcoma cells, is limited and poorly defined. Previously, we confirmed that melatonin at $4 \mathrm{mM}$ concentrations has an inhibitory effect on osteosarcoma cell proliferation by inducing $\mathrm{G}_{1}$ and $\mathrm{G}_{2} / \mathrm{M}$ phase arrest [3]. In the current study, we further document that melatonin induces $\mathrm{G}_{1}$ and $\mathrm{G}_{2} / \mathrm{M}$ phase arrest by downregulating the expression of cyclin D1, CDK4, cyclin B1 and CDK1; this is potentially mediated via the ERK1/2, but no p38, JNK, or Akt, signaling pathway.

Several studies using other cell types have indicated that MAPK and Akt signaling pathways are associated with melatonin-mediated antiproliferative actions [4-12]. We examined whether $4 \mathrm{mM}$ melatonin regulates the expression of MAPK components and Akt in a human osteosarcoma cell line MG-63. Our results suggest that melatonin significantly inhibited the phosphorylation of ERK1/2, which is consistent with previous reports [4,5]. However, melatonin had no significant influence on the phosphorylation of p38, JNK, or Akt, which contrasts with the findings of some studies in other cell types [4, 6-11]; the results indicate that these pathways do not play a central role in melatonin-induced cell cycle arrest in osteosarcoma cells. Moreover, the differences in cell types, melatonin concentrations used and time points at which the endpoints were examined could contribute to the lack of an apparent change in the phosphorylation of p38, JNK, or Akt. These findings indirectly suggest that ERK1/2 signaling pathway plays a key role in melatonin-regulated abnormal or normal osteoblast proliferation, such as the human osteosarcoma cell line MG-63 or osteoblastic cell line hFOB 1.19.

ERK1/2 activation has been well documented as necessary for cell proliferation, which is partly involved in $\mathrm{G}_{1}$ and $\mathrm{G}_{2} / \mathrm{M}$ phase progression [41-43]. As melatonin was capable of decreasing the expression of p-ERK1/2, we tested whether PD98059, a selective inhibitor of MEK that disrupts downstream activation of ERK1/2, would synergistically augment the antiproliferative effect of melatonin in MG-63 osteosarcoma cells. Our results demonstrated that PD98059 and melatonin alone, and especially in combination, significantly induced an antiproliferative effect, the $\mathrm{G}_{1}$ and $\mathrm{G}_{2} / \mathrm{M}$ phase arrest, and the downregulation of the expression at both protein and mRNA levels of cyclin D1 and CDK4 (related to the G1 phase) and of cyclin B1 and CDK1 (related to the G2/M phase) as measured by the MTT method, flow cytometry after PI staining, and both western blot and real-time PCR, respectively. Moreover, the combination synergistically and markedly enhanced the actions of PD98059 or melatonin alone. These findings strongly suggest that the prevention of ERK1/2 activation plays a central role in the observed melatonin-mediated actions.

Since a decline in both protein and mRNA levels of the cyclins and cyclin-dependent kinases was closely accompanied by a reduction in the expression of p-ERK1/2 after treatment with melatonin, we determined whether there is an interaction between $\mathrm{p}$-ERK1/2 and cyclin D1, CDK4, cyclin B1, or CDK1. Co-immunoprecipitation and reciprocal immunoprecipitation results strongly suggested an interaction between p-ERK1/2 and cyclin D1, CDK4, cyclin B1, or CDK1. This interaction was weakened by inhibiting the ERK1/2 signaling pathway with melatonin or PD98059. Melatonin effectively reduced phosphorylation of ERK1/2 rather than downregulating total ERK1/2 levels. The MG-63 cells used in the experiments were from the same treated batch and the results of figure 6 were trustworthy given that the data of figure 1 and 2 account for the equalization of total protein and total ERK1/2 levels among groups. Hence, the loss of protein in the immunoprecipitation of figure 6 is due to the loss of affinity but not total protein. These results demonstrate that the effects of melatonin on cell proliferation, cell cycle distribution, and the expression at both protein and mRNA levels of 
cyclin D1, CDK4, cyclin B1, and CDK1 can occur via the ERK1/2 pathway in human MG-63 osteosarcoma cells. In addition, a meta-analysis indicated that melatonin causes substantial improvements in tumor remission and alleviation of radiochemotherapy-related side effects [2]. Accordingly, our findings may well be helpful to exploring what it means in the context of inflammatory bone pain or bone metastases from all types of cancers: breast, ovarian, prostate, etc. Indeed, additional research should be encouraged.

Both the human MG-63 osteosarcoma cells and the normal mature osteoblast hFOB 1.19 cells are osteoblast-like cells, but they exhibit specific differential behaviors when they are exposed to identical concentrations of melatonin. When they were exposed to melatonin at $10 \mathrm{nM}-100 \mu \mathrm{M}$ concentrations, the hFOB cells exhibited increased cell proliferation while the MG-63 cells exhibit no change. When both cell types were exposed to melatonin at $1 \mathrm{mM}$ concentrations, by contrast, the proliferation of hFOB cells was markedly inhibited while the MG-63 cells exhibited no response; this only occurred in the latter cells when the concentration of melatonin reached $4 \mathrm{mM}$. Interestingly, the current data showed that melatonin-induced pro- or anti-proliferative actions in the hFOB [12] or MG-63 cells were mainly related to the ERK1/2 signaling pathway. Possible explanations for the apparent differences in this response may be a negative feedback loop or other regulated mechanisms having a role in the delayed response of osteoblast-like cells to melatonin. These findings suggest that there are obvious differences between the normal and cancer cells in the responsiveness to melatonin although they all are osteoblast-like cells. Additional research is necessary to mechanistically clarify these differential responses. This study suggests that the inhibition of ERK1/2, but not p38, JNK, or Akt, signaling pathway is involved in melatonin-induced $\mathrm{G}_{1}$ and $\mathrm{G}_{2} / \mathrm{M}$ phase arrest of the human MG-63 osteosarcoma cell line. This information may help clarify the regulatory mechanisms of melatonin supplementation in preventing the progression of some cancers and may provide useful information regarding the treatment of osteosarcoma with melatonin.

\section{Acknowledgements}

This work was supported by Program for Young Excellent Talents in Tongji University (1507219028), General Program from Shanghai Municipal Health Bureau (20134212), Training Program for Young Excellent Medical Talents of Pudong New Area Health System (PWRq2013-15), the Shanghai Medical Key Subject Construction Project (ZK2012A28), and the National Clinical Key Specialty Construction Project.

\section{Disclosure Statement}

The authors declare that they have no conflict of interest

\section{References}

1 Anninga JK, Gelderblom H, Fiocco M, Kroep JR, Taminiau AH, Hogendoorn PC, Egeler RM:

Chemotherapeutic adjuvant treatment for osteosarcoma: where do we stand? Eur J Cancer 2011;47:24312445.

2 Wang YM, Jin BZ, Ai F, Duan CH, Lu YZ, Dong TF, Fu QL: The efficacy and safety of melatonin in concurrent chemotherapy or radiotherapy for solid tumors: a meta-analysis of randomized controlled trials. Cancer Chemother Pharmacol 2012;69:1213-1220.

3 Liu L, Xu Y, Reiter RJ: Melatonin inhibits the proliferation of human osteosarcoma cell line MG-63. Bone 2013;55:432-438.

4 Cui P, Yu M, Luo Z, Dai M, Han J, Xiu R, Yang Z: Intracellular signaling pathways involved in cell growth inhibition of human umbilical vein endothelial cells by melatonin. J Pineal Res 2008;44:107-114. 


\section{Cellular Physiology Cell Physiol Biochem 2016;39:2297-2307 \begin{tabular}{l|l|l} 
and Biochemistry $\begin{array}{l}\text { DOI: 10.1159/000447922 } \\
\text { Published online: November 07, 2016 }\end{array}$ & $\begin{array}{l}\text { (c) } 2016 \text { The Author(s). Published by S. Karger AG, Basel } \\
\text { www.karger.com/cpb }\end{array}$
\end{tabular}}

Liu et al.: ERK1/2 Involves Melatonin-inhibited Osteosarcoma Cell Proliferation

5 Nah SS, Won HJ, Park HJ, Ha E, Chung JH, Cho HY, Baik HH: Melatonin inhibits human fibroblast-like synoviocyte proliferation via extracellular signal-regulated protein kinase/P21(CIP1)/P27(KIP1) pathways. J Pineal Res 2009;47:70-74.

6 Martín-Renedo J, Mauriz JL, Jorquera F, Ruiz-Andrés O, González P, González-Gallego J: Melatonin induces cell cycle arrest and apoptosis in hepatocarcinoma HepG2 cell line. J Pineal Res 2008;45:532-540.

7 Cabrera J, Negrín G, Estévez F, Loro J, Reiter RJ, Quintana J: Melatonin decreases cell proliferation and induces melanogenesis in human melanoma SK-MEL-1 cells. J Pineal Res 2010;49:45-54.

8 Martín V, Herrera F, Carrera-Gonzalez P, García-Santos G, Antolín I, Rodriguez-Blanco J, Rodriguez C: Intracellular signaling pathways involved in the cell growth inhibition of glioma cells by melatonin. Cancer Res 2006;66:1081-1088.

9 Martín V, Herrera F, García-Santos G, Antolín I, Rodriguez-Blanco J, Medina M, Rodriguez C: Involvement of protein kinase C in melatonin's oncostatic effect in C6 glioma cells. J Pineal Res 2007;43:239-244.

10 Proietti S, Cucina A, D‘Anselmi F, Dinicola S, Pasqualato A, Lisi E, Bizzarri M: Melatonin and vitamin D3 synergistically down-regulate Akt and MDM2 leading to TGF $\beta$-1-dependent growth inhibition of breast cancer cells. J Pineal Res 2011;50:150-158.

11 Hill SM, Belancio VP, Dauchy RT, Xiang S, Brimer S, Mao L, Hauch A, Lundberg PW, Summers W, Yuan L, Frasch T, Blask DE: Melatonin: an inhibitor of breast cancer. Endocr Relat Cancer 2015;22:R183-R204.

12 Liu L, Zhu Y, Xu Y, Reiter RJ: Prevention of ERK activation involves melatonin-induced G(1) and G(2) /M phase arrest in the human osteoblastic cell line hFOB 1.19. J Pineal Res 2012;53:60-66.

13 Chang L, Karin M: Mammalian MAP kinase signalling cascades. Nature 2001;410:37-40.

14 Johnson GL, Lapadat R: Mitogen-activated protein kinase pathways mediated by ERK, JNK, and p38 protein kinases. Science 2002;298:1911-1912.

15 Tan J, Wang Y, Xia Y, Zhang N, Sun X, Yu T, Lin L: Melatonin protects the esophageal epithelial barrier by suppressing the transcription, expression and activity of myosin light chain kinase through ERK1/2 signal transduction. Cell Physiol Biochem 2014;34:2117-2127.

16 Hayne C, Tzivion G, Luo Z: Raf-1/MEK/MAPK pathway is necessary for the G2/M transition induced by nocodazole. J Biol Chem 2000;275:31876-31882.

17 Davis RJ: Signal transduction by the JNK group of MAP kinases. Cell 2000;103:239-252.

18 Li W, Fan M, Chen Y, Zhao Q, Song C, Yan Y, Jin Y, Huang Z, Lin C, Wu J: Melatonin Induces Cell Apoptosis in AGS Cells Through the Activation of JNK and P38 MAPK and the Suppression of Nuclear Factor-Kappa B: a Novel Therapeutic Implication for Gastric Cancer. Cell Physiol Biochem 2015;37:2323-2338.

19 Roulston A, Reinhard C, Amiri P, Williams LT: Early activation of c-Jun N-terminal kinase and p38 kinase regulate cell survival in response to tumor necrosis factor alpha. J Biol Chem 1998;273:10232-10239.

20 Kulik G, Klippel A, Weber MJ: Antiapoptotic signalling by the insulin-like growthfactor I receptor, phosphatidylinositol 3-kinase, and Akt. Mol Cell Biol 1997;17:1595-1606.

21 Kauffmann-Zeh A, Rodriguez-Viciana P, Ulrich E, Gilbert C, Coffer P, Downward J, Evan G: Suppression of c-Myc-induced apoptosis by Ras signalling through PI(3)K and PKB. Nature 1997;385:544-548.

22 Dudek H, Datta SR, Franke TF, Birnbaum MJ, Yao R, Cooper GM, Segal RA, Kaplan DR, Greenberg ME: Regulation of neuronal survival by the serine-threonine protein kinase Akt. Science 1997;275:661-665.

23 Brunet A, Bonni A, Zigmond MJ, Lin MZ, Juo P, Hu LS, Anderson MJ, Arden KC, Blenis J, Greenberg ME: Akt promotes cell survival by phosphorylating and inhibiting a Forkhead transcription factor. Cell 1999;96:857-868.

24 Liu L, Zhu Y, Xu Y, Reiter RJ: Melatonin delays cell proliferation by inducing G1 and G2 /M phase arrest in a human osteoblastic cell line hFOB 1.19. J Pineal Res 2011;50:222-231.

25 Kim JE, Ahn MW, Baek SH, Lee IK, Kim YW, Kim JY, Dan JM, Park SY: AMPK activator, AICAR, inhibits palmitate-induced apoptosis in osteoblast. Bone 2008;43:394-404.

26 Xu Y, Liu L, Qiu X, Jiang L, Huang B, Li H, Li Z, Luo W, Wang E: CCL21/CCR7 promotes G2/M phase progression via the ERK pathway in human non-small cell lung cancer cells. PLoS One 2011;6:e21119.

27 Vriend J, Reiter RJ: Melatonin feedback on clock genes: a theory involving the proteasome. J Pineal Res 2015;58:1-11.

28 Hablitz LM, Molzof HE, Abrahamsson KE, Cooper JM, Prosser RA, Gamble KL: GIRK Channels Mediate the Nonphotic Effects of Exogenous Melatonin. J Neurosci 2015;35:14957-14965.

29 Lewy AJ, Bauer VK, Singer CM, Minkunas DV, Sack RL: Later circadian phase of plasma melatonin relative to usual wake time in older subject. Sleep 2000;23:A188-A189. 


\section{Cellular Physiology Cell Physiol Biochem 2016;39:2297-2307 \begin{tabular}{l|l|l} 
DOI: 10.1159/000447922 & $\begin{array}{l}\text { O 2016 The Author(s). Published by S. Karger AG, Basel } \\
\text { www.karger.com/cpb }\end{array}$
\end{tabular} \\ Liu et al.: ERK1/2 Involves Melatonin-inhibited Osteosarcoma Cell Proliferation}

30 Tozawa T, Mishima K, Satoh K, Echizenya M, Shimizu T, Hishikawa Y: Stability of seep timing against the melatonin secretion rhythm with advancing age: clinical implications. J Clin Endocrinol Metab 2003;88:4689-4695.

31 Galano A, Tan DX, Reiter RJ: Melatonin as a natural ally against oxidative stress: a physicochemical examination. J Pineal Res 2011;51:1-16.

32 Garcia JJ, López-Pingarrón L, Almeida-Souza P, Tres A, Escudero P, García-Gil FA, Tan DX, Reiter RJ, Ramírez JM, Bernal-Pérez M: Protective effects of melatonin in reducing oxidative stress and in preserving the fluidity of biological membranes. J Pineal Res 2014;56:225-237.

33 Kang JW, Cho HI, Lee SM: Melatonin inhibits mTOR-dependent autophagy during liver ischemia/ reperfusion. Cell Physiol Biochem 2014;33:23-36.

34 Manchester LC, Coto-Montes A, Boga JA, Andersen LP, Zhou Z, Galano A, Vriend J, Tan DX, Reiter RJ: Melatonin: an ancient molecule that makes oxygen metabolically tolerable. J Pineal Res 2015;59:403-419.

35 Reiter RJ, Mayo JC, Tan DX, Sainz RM, Alatorre-Jimenez M, Qin L: Melatonin as an antioxidant: under promises but over delivers. J Pineal Res 2016;61:253-278.

36 Ali T, Badshah H, Kim TH, Kim MO: Melatonin attenuates D-galactose-induced memory impairment, neuroinflammation and neurodegeneration via RAGE/NF- $\mathrm{B}-\mathrm{KB} / \mathrm{JNK}$ signaling pathways in aging mouse. J Pineal Res 2015;58:76-85.

37 Yun M, Kim EO, Lee D, Kim JH, Kim J, Lee H, Lee J, Kim SH: Melatonin sensitizes H1975 non-small-cell lung cancer cells harboring a T790M-targeted epidermal growth factor receptor mutation to the tyrosine kinase inhibitor gefitinib. Cell Physiol Biochem 2014;34:865-872.

38 Li Y, Zhang Z, He C, Zhu K, Xu Z, Ma T, Tao J, Liu G: Melatonin protects porcine oocyte in vitro maturation from heat stress. J Pineal Res 2015;59:365-375.

39 Maria S, Witt-Enderby P: Melatonin effects on bone: potential use for the prevention and treatment for osteopenia, osteoporosis, and periodontal disease and for use in bone-grafting procedures. J Pineal Res 2014;56:115-125.

40 Sánchez-Barceló EJ, Mediavilla MD, Tan DX, Reiter RJ: Scientific basis for the potential use of melatonin in bone diseases: osteoporosis and adolescent idiopathic scoliosis. J Osteoporos 2010;2010:830231.

41 Chambard JC, Lefloch R, Pouysségur J, Lenormand P: ERK implication in cell cycle regulation. Biochim Biophys Acta 2007;1773:1299-1310.

42 Meloche S, Pouysségur J: The ERK1/2 mitogen-activated protein kinase pathway as a master regulator of the G1- to S-phase transition. Oncogene 2007;26:3227-3239.

43 Bodart JF: Extracellular-regulated kinase-mitogen-activated protein kinase cascade: unsolved issues. J Cell Biochem 2010;109:850-857. 